\title{
Ignoring puff counts: another shortcoming of the Federal Trade Commission cigarette testing programme
}

\author{
L T Kozlowski, ${ }^{1}$ C A Whetzel, ${ }^{2}$ S D Stellman, ${ }^{3}$ R J O'Connor ${ }^{4}$
}

${ }^{1}$ Department of Health Behavior, State University of New York at Buffalo, Buffalo, NY, USA;

${ }^{2}$ Department of Biobehavioral Health, Pennsylvania State University, University Park, PA, USA; ${ }^{3}$ Department of

Epidemiology, Mailman School of Public Health, Columbia University, New York, NY, USA;

${ }^{4}$ Department of Health Behavior, Roswell Park Cancer Institute, Buffalo, NY, USA

Correspondence to: Dr Lynn T Kozlowski,

Department of Health Behavior, School of Public Health and Health Professions, University at Buffalo, 623 Kimball Tower, Buffalo, NY 14214-3079, USA; lk22@buffalo.edu

Received 9 February 2007 Accepted 18 June 2007

\section{ABSTRACT}

Objectives: To examine reasons behind the failure of the Federal Trade Commission (FTC) to preserve puff count information from standard cigarette testing and to elucidate the importance of puff count to overall tar yields. Methods: We reviewed industry documents on origins of the FTC test and datasets provided by the Tobacco Institute Testing Laboratory to the tobacco industry and FTC for reporting purposes.

Results: The majority of the tobacco industry argued for "dual reporting" of tar yields - both per cigarette and per puff. Despite a request from the Tobacco Institute in 1967 that puff count information be preserved, documents and recent communications with the FTC indicate that puff number data have not been maintained by the government. In contrast, for the cigarette industry, puff count data are a fundamental and routine part of testing and important to cigarette design. A sample of puff counts for cigarettes tested in $1996(n=471)$ shows that on average $100 \mathrm{~mm}$ cigarettes have 18\% more puffs taken on them than do $85 \mathrm{~mm}$ cigarettes in standard tests (7.66 vs $9.03 ; p<0.01)$. The 10 th percentile puff count is 6.8 and the 90th percentile is 8.8 for king size; the 10th percentile puff count is 8.2 and the 90th percentile is 10.0 for $100 \mathrm{~mm}$ cigarettes, indicating that puff counts can vary substantially among brands.

Conclusions: The FTC has failed to seek or preserve puff count information that the industry finds important. Any standard test of tar and nicotine yields should at minimum preserve puff count information.

Owing to pressure from congressional leaders, in 1966 the United States Federal Trade Commission (FTC) began evaluating procedures for standardised testing of cigarettes for tar and nicotine yields. ${ }^{12}$ The immediate source of the test procedure was a report by a government chemist, CL Ogg, in the Journal of Association of Official Agricultural Chemists in 1964. ${ }^{3}$ The basic smoking parameters had been established somewhat arbitrarily by researchers for the American Tobacco Company almost three decades earlier. ${ }^{4}$ Both the Ogg and FTC cigarette test specified a 2 second puff, every 60 seconds, until a fixed butt length was reached, but the butt length rules differed somewhat as did the pre-smoking environmental conditioning procedures. A test based on a fixed puffing rate can achieve differing numbers of puffs per cigarette (depending on the burn rate of tobacco during and in between puffs and the length of the cigarette).

Transcripts from the FTC hearings in 1966 on the testing procedure reveal two main issues: (1) the butt length to which cigarettes would be smoked (23 $\mathrm{mm}$ vs $30 \mathrm{~mm}$ at the shortest) and (2) whether there would be "dual reporting" of tar yields-that is, reporting of tar yield "per cigarette" as well as "tar yield per puff," achieved by dividing the per cigarette yield by the puff count. ${ }^{5}$ The transcripts show various concerns about dual reporting. The first was possible confusion to the consumer by showing too much information. The FTC hearings also revealed the concern that a puff would not mean much to the consumer: "He doesn't smoke a puff, he smokes a cigarette." The second was the ambiguity of an average "per puff" value, given that the actual "per puff" amount of many mainstream smoke constituents increases with each puff. ${ }^{5}$ Most of the cigarette companies were supportive of dual reporting, but Lorillard was against it. ${ }^{6}$ For cigarettes that gave lower tar yields primarily because fewer puffs were taken on them, "per puff" reporting would make them look like higher tar cigarettes and raise questions about the utility of the "per cigarette" value. ${ }^{5}$

Just before formal FTC testing began, the president of the Tobacco Institute sent a letter to the chairman of the FTC requesting that, since the smoking machines used automatically indicated puff counts, the puff count data be preserved as part of the record.' We were unable to find a response to this letter, but we do know that the puff count information was not generally preserved as part of the record, both from earlier inquiries with the then chemist in charge of the FTC laboratory (the late Harold Pillsbury) and from a recent email inquiry (personal communication from Shira Modell to Lynn Kozlowski 14 Sept 2004). Despite early arguments for preserving per puff information, a written request from the Tobacco Institute to preserve puff count information in the FTC archives, and later publications arguing for the importance of puff count information, ${ }^{89}$ as far as we have been able to determine preservation of puff counts did not become a routine part of the practice of the FTC laboratory.

In 1987 the FTC decided to close its laboratory but continued to publish its reports of mainstream smoke yields using data obtained directly from the Tobacco Institute Testing Laboratory (TITL). ${ }^{10}$ This laboratory had been created by cigarette manufacturers in 1966, around the start of FTC testing, in part to provide a check on the FTC results. With the Master Settlement Agreement, the Tobacco Institute was closed and the testing laboratory became the industry sponsored "Tobacco Industry Testing Laboratory" (also 
abbreviated TITL) in early February 1999. ${ }^{11}$ In our exploration of tobacco industry documents, we discovered several results from the TITL that included puff count information ${ }^{12}{ }^{13}$ and even evidence of the existence of computer data files including puff counts. ${ }^{14}$ The FTC's continued failure to maintain or report puff count information may simply be because of its failure to request these data from the TITL, although records we have examined clearly show that such data are available.

If puff counts were very similar on all or even most cigarettes, it might be of little practical interest to know the exact puff counts for different cigarette brands. However, if puff counts vary substantially, it does support the need to at least preserve this information in the future for research purposes. The industry documents show multiple ways that the companies could manipulate puff counts. For example, RJ Reynolds noted more than 15 ways to change puff counts beyond changing cigarette paper (for example, higher porosity paper burns faster), including, for example, tobacco types, stalk position, circumference, tobacco rod packing density, pack moisture, addition of propylene glycol, humectants and sugars. ${ }^{15}$ If nothing else is done to a cigarette but the addition of filter ventilation, puff counts will be increased, because each puff is consuming less and less tobacco as ventilation increases. ${ }^{16}$ The fixed puffing parameters and butt length setting of the FTC test do not in a rigid way determine the puff count taken during a standard test: such design features as brand differences in rod length, filter length, overwrap length, tobacco density, paper porosity and chemical additives to the paper or tobacco rod can produce quite different puff counts.

Because of the failure to preserve this information by the FTC, sources in tobacco industry documents become a key resource for exploring the nature of different types of cigarettes. To explore the magnitude of the problem of not knowing puff counts of cigarettes in the FTC test, we characterised relevant data reported by TITL in 1996 by analysing puff counts in relation to FTC tar and nicotine yield, cigarette length ( $85 \mathrm{~mm}$ vs $100 \mathrm{~mm}$ ), and presence or absence of a filter ${ }^{17}$ We reasoned that if tar yields were highly correlated with puff counts, they would be unlikely to provide additional useful information beyond what was already publicly known, because tar yields have not proved to be a useful measure of cigarette risk. ${ }^{18}$

\section{METHODS}

We used an industry document that reported TITL data, including puff counts, from $1996 .{ }^{17}$ The dataset was analysed using SPSS to calculate descriptive statistics and regressions. Key variables were FTC tar and nicotine yields, puff counts, filter (present or absent) and cigarette length (king size $(n=233)$ vs $100 \mathrm{~mm}(n=238))$. The exact measured length of the cigarettes was not always exactly $85 \mathrm{~mm}$ or $100 \mathrm{~mm}$ and could have been $1 \mathrm{~mm}$ or so shorter. In regression analyses, no adjustments were made for varietal members of the same brand family (for example, Marlboros with different pack types) because varieties of the same brand may vary widely in yield and puff count. Each cigarette brand/variety was treated as an independent observation. There were too few $70 \mathrm{~mm}(\mathrm{n}=7)$ and $120 \mathrm{~mm}(\mathrm{n}=24)$ cigarettes for useful analysis. Only domestic brands from major manufacturers were analysed. Cigarette brands were categorised according to their FTC tar yields as ultralight ( $\leqslant 6.3 \mathrm{mg}$ tar), light $(6.4-15.3 \mathrm{mg}$ ) and full flavour ( $\geqslant 15.4 \mathrm{mg}$ ). Regression analyses utilised FTC yields as continuous variables.

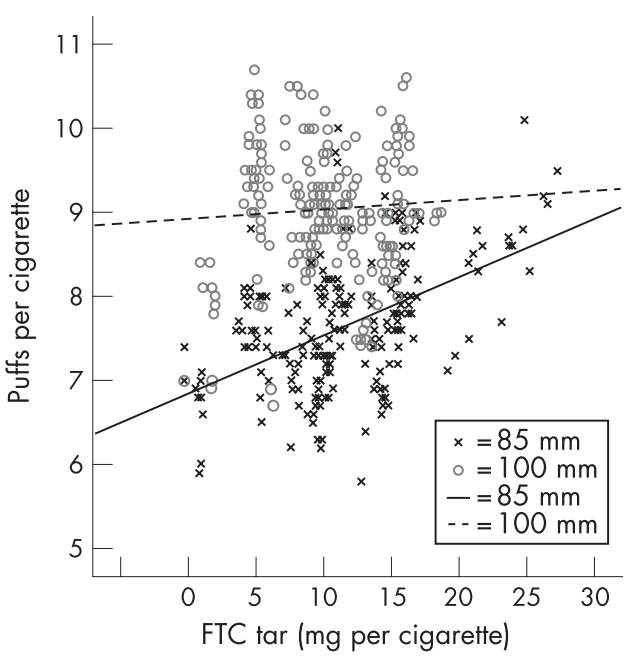

Figure 1 Puff counts vs FTC tar yields for all $85 \mathrm{~mm}(\mathrm{n}=236)$ and $100 \mathrm{~mm}(\mathrm{n}=238)$ cigarettes, Tobacco Institute Testing Laboratory data, 1996. Analyses include both filter and non-filter cigarettes.

\section{RESULTS}

Puff count was significantly correlated with FTC nicotine $(\rho=0.262, p<0.01)$ and somewhat less strongly with FTC tar $(\rho=0.107, p<0.05)$. These correlations varied substantially by cigarette length, and were much stronger in $85 \mathrm{~mm}$ than $100 \mathrm{~mm}$ cigarettes: for $85 \mathrm{~mm}$ cigarettes the correlation for FTC nicotine was $0.617(p<0.01)$ and for FTC tar it was $0.481(p<0.01)$. In $100 \mathrm{~mm}$ cigarettes the correlation between puff count and FTC nicotine was reduced to $0.207(p<0.01)$ and for FTC tar it became non-significant at 0.059 . Figure 1 displays a scatter plot of the puff count data, which includes separate regression lines for $85 \mathrm{~mm}$ and $100 \mathrm{~mm}$ cigarettes. The regression equation for puff count as a function of FTC tar in $85 \mathrm{~mm}$ cigarettes was:

\section{puff count $=6.86+0.069($ FTC tar $)(85 \mathrm{~mm})$}

The $95 \%$ confidence interval about the regression coefficient was (0.053 to 0.085$)$ - that is, significantly greater than zero. For $100 \mathrm{~mm}$ cigarettes the regression equation was:

puff count $=8.93+0.010($ FTC tar $)(100 \mathrm{~mm})$

for which the $95 \%$ confidence interval about the regression coefficient was ( -0.012 to 0.085$)$, not significantly different from zero.

There were only 18 non-filter brands of $85 \mathrm{~mm}$ cigarettes (7.6\% of 236 brands/varieties); no $100 \mathrm{~mm}$ non-filter brands were found in the TITL dataset. The non-filtered cigarettes had significantly more $\operatorname{tar}(\mathrm{n}=18$, mean 23.13 (SD 2.45) mg; range $8.2 \mathrm{mg}$ ) than did filtered $85 \mathrm{~mm}$ cigarettes $(\mathrm{n}=217$, mean 10.70 $(4.32) \mathrm{mg}$, range $17.5 \mathrm{mg})(\mathrm{p}<0.05)$. In separate regressions for filter and non-filter cigarettes, the regression coefficient for nonfilters ( $b=0.23$; $95 \%$ CI 0.13 to 0.33 ) was significantly greater than that for filter cigarettes $(b=0.06$; $95 \%$ CI 0.04 to 0.08$)$ although the latter was still significantly different from zero.

Figure 2 shows a plot of average puff counts as a function of three tar categories (ultralight, light and full flavour), with separate lines drawn for $85 \mathrm{~mm}$ and $100 \mathrm{~mm}$ cigarettes. Reliably, $100 \mathrm{~mm}$ have more puffs taken than do $85 \mathrm{~mm}$ cigarettes in standard tests $(\mathrm{F}(1,469)=338.9 ; \mathrm{p}<0.05)$. There is a main effect for tar yield category $(\mathrm{F}(2,469)=26.02 ; \mathrm{p}<0.05)$, and a small, non-crossover interaction between length and tar category $(F(2,469)=3.85 ; p<0.05)$. Inspection of the plot and Bonferroni post hoc comparison tests (significant at $\mathrm{p}<0.017$ ) 


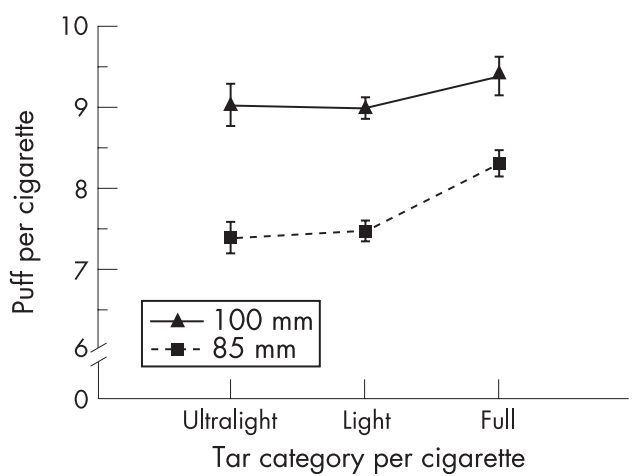

Figure 2 Graph of $85 \mathrm{~mm}$ length and $100 \mathrm{~mm}$ length full flavour (>15 mg tar), light (7-15 mg tar) and ultralight ( $<7 \mathrm{mg}$ tar) categories and subsequent puff counts. Error bars represent $95 \%$ confidence intervals.

indicate no difference in puff counts between ultralight and light cigarettes, but full flavour cigarettes overall have higher puff counts than do either ultralight or light cigarettes.

For the entire sample of $85 \mathrm{~mm}$ and $100 \mathrm{~mm}$ cigarettes, the mean number of puffs was 8.36, $\mathrm{SD}=1.02, \mathrm{IOR}=1.5$, minimum $=5.8$, maximum $=10.7$. For the best selling light tar group for $85 \mathrm{~mm}$ and $100 \mathrm{~mm}$ cigarettes, the mean number of puffs was 8.26, $\mathrm{SD}=1.01, \mathrm{IOR}=1.6$, minimum $=5.8$, maximum $=10.5$.

\section{DISCUSSION}

Our analysis shows that puff counts vary widely among US domestic cigarettes, ranging between about 6 and 11 puffs, with $100 \mathrm{~mm}$ cigarettes providing significantly more puffs than $85 \mathrm{~mm}$ brands. FTC nicotine and tar are strong predictors of puff counts in $85 \mathrm{~mm}$ but not $100 \mathrm{~mm}$ brands, and there is no difference in puff counts between cigarettes with low and ultralow FTC yields.

The FTC test has been already heavily criticised as being unrepresentative of human exposure $e^{18-20}$ and it is at present unclear whether the FTC will be issuing any further reports of tar and nicotine yields. Nevertheless, we think it worth noting that the FTC has ignored what might be learned from puff count or per puff information on tar and nicotine yields. Should the test reports resume or a new test be adopted, it would be important to start preserving puff count information as one aspect of the test.

In 1980, Kozlowski et al used puff count data from the Canadian cigarette testing laboratory to demonstrate that much of the apparent decrease in tar yields at the time was probably the result of small decreases in puff counts. ${ }^{8}$ Small decreases in puff counts present little barrier to compensation. If a smoker is faced with a cigarette that burns a little faster, taking the additional puff or two to compensate is a very easy matter.

In a system in which puff counts are free to vary to the extent observed (see fig 1), the recording of puff counts should be a fundamental laboratory practice when measuring tar and nicotine yields. It was such an important principle in Ogg's original 1964 study that data from one laboratory were excluded because of implausibly high puff counts and data from two other laboratories were excluded because of implausibly high puff counts in conjunction with high total particulate matter (TPM minus water and nicotine equals "tar") and nicotine. ${ }^{3}$

With puff count data, one can calculate a summary measure of tar or nicotine per puff. Since its start, it appears that the Tobacco Institute Testing Laboratory collected puff counts and often produced tables reporting yields per puff (for example, TITL market samples 1-7-1968-1970). The immediate sensory effects of a cigarette are carried by individual puffs, and in cigarette taste testing, participants typically take only a few puffs to evaluate a product. ${ }^{21}$ Tar per puff and puff count design specifications have been critical in cigarette manufacturing for many years, and it has been routine industry practice to record puff counts and yields per puff. ${ }^{22}{ }^{23}$ In exploring ways to reduce tar and nicotine yields, Philip Morris researchers tried to maintain puff counts of their "current Marlboro" while developing alternative prototypes. ${ }^{24}$ In a 1996 programme at Philip Morris on product development, one apparent slide concerning the "Blend Development Group" included both "tar" and "puff count" under the rubric "Analytical Target," while another slide labelled "Cigarette Design \& Development" noted that cigarettes needed to be constructed to achieve the desired: "Subjective Requirements, Tar, Tar/Puff, Size (Circumference, Length), Firmness (Weight, OV)." 25 This document also includes several graphs plotting "liking" for a cigarettes as a function of tar/puff. Even the Lorillard Company, which had expressed opposition to reporting tar on a per puff basis, ${ }^{72}$ did show attention to puff counts in cigarette design, noting in a 1982 consideration of TITL puff count results: "The brands that are more than 0.5 puffs below the trend lines are marked with an asterisk and are considered to be in a potentially poor competitive position. It should be noted that only two Lorillard brands are above trend lines." ${ }^{\prime 27}$ In 1989, RJ Reynolds started a "puff count increase programme" to increase the puff counts on selected brand styles to "parity" with competing brands. ${ }^{28}$

In a 1986 Philip Morris document, possibly a speech, the problem of increasing puff counts as a result of filter ventilation was noted, and it was described as "critical" to maintain a "specific, 'tar per puff,' to help maintain 'smoke impact' and "taste." ${ }^{29}$ Design manipulations to alter static burn rate of the tobacco column were seen as key to controlling puff count.

It is unclear why the FTC never recorded puff count information. Perhaps they believed that per puff reporting would confuse the public and were so set against it that they did not want to have the ability to do so, even at a later date. All parties agreed that there is no uniform tar amount per puff: tar increases as more puffs are taken as the cigarette burns down, and two cigarettes with identical FTC tar and nicotine yields and discrepant puff counts will be different cigarettes on a "per puff" basis, and they will tend to burn for different amounts of time in the standard test (controlling for length). Since the $100 \mathrm{~mm}$ cigarette was first entering the market around the time the FTC test was starting, there may have been a desire to avoid comparing cigarettes on a "tar per puff" basis, which could have made longer, higher "tar per cigarette" brands equivalent to shorter cigarettes on a "tar per puff" basis. The "tar per cigarette" may have seemed to be a better single measure to avoid this discrepancy.

A number of individuals and public health organisations have recently made recommendations for more extensive monitoring of tobacco products. In 2002 the Agent (product) Working Group of the National Tobacco Monitoring, Research and Evaluation Workshop recommended an extensive research programme to improve methods to assess uptake and metabolism of these constituents which take into account variability in human smoking behaviour. ${ }^{30}$ In 2005 the World Health Organization established the Tobacco Laboratory Network (TobLabNet), one of whose goals is to "develop additional methods and create a validation programme for testing methods 


\section{What this paper adds}

- US Federal Trade Commission (FTC) testing of cigarettes for tar and nicotine yields began in 1967. Despite requests that puff count information be preserved, puff number data have not been maintained by the FTC.

- In contrast, for the cigarette industry, puff count data are a fundamental and routine part of testing and important to cigarette design.

- Examination of tobacco industry documents and testing data reveals that on average $100 \mathrm{~mm}$ cigarettes have $18 \%$ more puffs taken on them than do $85 \mathrm{~mm}$ cigarettes in standard tests.

- Puff counts can vary substantially among brands, even within broad classifications such as light or ultralight.

- Any standard test of tar and nicotine yields should at minimum preserve puff count information.

for tobacco products and tobacco smoke other than tar, nicotine, and carbon monoxide." ${ }^{131}$ Until such recommendations are implemented by governmental bodies, the FTC will continue to be the statutory authority for industry-wide tobacco product surveillance in the US. We strongly recommend that the FTC request puff count information as part of the data it receives from the TITL and make it available to researchers and the public as part of its published reports. The labour required in getting the information is insignificant relative to the cost of the testing system as a whole. It is hard to think of a good reason why this basic aspect of the test outcome should not be archived by the government, and it is also hard to think why these data should not be published. If and when a revised test is adopted, we hope that puff count information will become part of the historical record. Since standard tar tests around the world do not fix puff counts, it would be good to explore predictive relations with "per puff" yields as well as "per cigarette" yields, along with toxicological, epidemiological and sales data.

Funding: This research was funded by a grant from the US National Cancer Institute 15 R01 CA 095890) and via the Roswell Park Transdisciplinary Tobacco Use Research Center (TTURC; 1 P50 CA111236).

Competing interests: None.

\section{REFERENCES}

1. Kluger R. Ashes to ashes: America's hundred-year cigarette war, the public health, and the unabashed triumph of Philip Morris. New York: Alfred A Knopf, 1996.

2. Peeler CL. Cigarette testing and the Federal Trade Commission: a historical overview. In: The FTC cigarette test method for determining tar, nicotine, and carbon monoxide yields of US cigarettes. Smoking and Tobacco Control Monograph 7. Bethesda, MD: National Cancer Institute, 1996.

3. Ogg CL. Determination of particulate matter and alkaloids (as nicotine) in cigarette smoker. J Assoc Ag Chem 1964;47:356-62.
4. Bradford JA, Harlan WR, Hanmer HR. Nature of cigarette smoke: technique of experimental smoking. Ind Eng Chem 1936;28:836-9.

5. Bock FG and commission. FTC hearing transcript. 30 November 1966. Brown and Williamson http://legacy.library.ucsf.edu/tid/pyb24f00.

6. Spears AW. [Summary Statement] 30 November 1966. Lorillard.http://legacy. library.ucsf.edu/tid/uwp10e00.

7. Clements EC. [Letter] 4 August 1967. Philip Morris. http://legacy.library.ucsf.edu/ $\mathrm{tid} / \mathrm{ndi} 74 \mathrm{e} 00$.

8. Kozlowski LT, Rickert WS, Robinson JC, et al. Have tar and nicotine yields of cigarettes changed? Science 1980;209:1550-1.

9. Kozlowski LT. Tar and nicotine delivery of cigarettes: what a difference a puff makes. JAMA 1981;245:158-9.

10. Federal Trade Commission. Report on "tar", nicotine, and carbon monoxide 1998. Washington DC: Federal Trade Commission, 2000 http://www.ftc.gov/reports/ tobacco/1998tar\&nicotinereport.pdf.

11. Daigle WP. [Memo] 1 February 1999. Lorillard. http://legacy.library.ucsf.edu/tid/ tqe72d00.

12. Thompson WC. Tare and puff count-TITL market sample № 25. 7 Apr 1982 Lorillard. http://legacy.library.ucsf.edu/tid/uiu31e00 Bates № 80005434.

13. Jones RM. Comparison of smoking results form TITL \& PM. 26 June 1990. Philip Morris. http://legacy.library.ucsf.edu/tid/xtt17e00.

14. Steele WL. [Letter and data] 3 March 1994. Brown and Williamson. http://legacy. library.ucsf.edu/tid/hgj93f00.

15. Perfetti PF, et al. A literature review of factors that influence cigarette puff count. 10 May 1994. RJ Reynolds. http://legacy.library.ucsf.edu/tid/yiw53d00.

16. Phillip Morris. Cigarettes a la carte. Phillip Morris, 1988. http://legacy.library.ucsf edu/tid/mti98e00.

17. TITL MS \#39 1996 YE sales. ND. 1996. Philip Morris.http://legacy.library.ucsf.edu/ tid/ais66c00.

18. Burns DM, Major JM, Shanks TG, et al. Smoking lower yield cigarettes and disease risks. In: Risks associated with smoking cigarettes with low machine-measured yields of tar and nicotine. Smoking and Tobacco Control Monograph 13. Bethesda MD: National Cancer Institute, 2001

19. Kozlowski LT, O'Connor RJ. Official cigarette tar test are misleading: use a twostage, compensating test. Lancet 2000;355:2159-61.

20. Kozlowski LT, O'Connor R, Giovino G, et al. Maximum yields might improve public health —if filter vents were banned: a lesson from the history of vented filters. Tob Control 2006;15:262-6.

21. Abdallah F. Cigarette product development. Raleigh, NC: Tobacco Reporter SpecComm International, Inc, 2004.

22. Ikeda RM, Sanderson KL, Wickham JE. Evaluation report Cl Report number 9-68. 30 Sept 1968. Philip Morris. http://legacy.library.ucsf.edu/tid/fgs76e00.

23. Giles JA. Reporting of analytical data on competitive brands. 14 Sept 1967. RJ Reynolds. http://legacy.library.ucsf.edu/tid/rzt43d00.

24. Merritt HB. Upper leaves vs lower leaves. 9 Oct 1967. Philip Morris. http://legacy. library.ucsf.edu/tid/luq84e00.

25. PM USA. Product development. Presentation. 2 July 1994. Philip Morris. http:// legacy.library.ucsf.edu/tid/pqd36e00.

26. Wald RL. [Letter]. 1 Sept 1966. Lorillard.http://legacy.library.ucsf.edu/tid/cbl90e00

27. Thompson WC. Tar and puff count_-TITL market sample No 25. 7 April 1982. Lorillard. http://legacy.library.ucsf.edu/tid/uiu31e00.

28. lauco DN. Puff count increase program. 5 Sept 1989. RJ Reynolds. http://legacy. library.ucsf.edu/tid/nmb34d00.

29. Philip Morris. The control of cigarette smoke deliveries - an overview. April 1986 Philip Morris. http://legacy.library.ucsf.edu/tid/kjf29e00.

30. Giovino GA, Biener L, Stellman SD, et al. Summary of workgroup recommendations: National Tobacco Monitoring Research, and Evaluation Workshop. 4-6 November 2002, Bethesda, Maryland USA. Available from http://roswell.tobaccodocuments.org/ Work\%20Group\%20Rec.doc/

31. World Health Organization. The first meeting of the WHO Tobacco Laboratory Network (TobLabNet) on 28 and 29 April 2005 in The Hague, Netherlands. 2005; Available from: http://www.who.int/tobacco/global_interaction/tobreg/laboratory/en/, Accessed 4 May 2007. 